\title{
Writing a Novel with Roma Primary School Children: Tensions in Disrupting Aetonormativity
}

\author{
Tom Dobson $^{1}$ (D) . Lisa Stephenson ${ }^{1} \cdot$ Ana De Arede $^{1}$
}

Accepted: 15 October 2020 / Published online: 7 November 2020

(c) The Author(s) 2020

\begin{abstract}
Story Makers Press (SMP) is a University-based publisher which co-constructs stories with under-represented groups of children in order to diversify representation in children's literature and disrupt the way adult perceptions of normality pattern children's literature (aetonormativity). In this paper we analyse six drama and creative writing workshops run by SMP with Czech and Slovak Roma children from an inner city primary school in the north of England to co-construct a story about climate change. Our analysis identifies how in developing the story, the children were often reluctant to draw upon their funds of knowledge relating to their Roma backgrounds, instead Westernising their protagonists and settings. We also explore how the children disrupt aetonormativity by interweaving magical elements into realistic narrative about climate change in order to establish a genre of magical realism. Finally, we identify how this genre of magical realism is problematic when considering stereotypical depictions of Roma characters in children's literature and how changes were made to our story in light of a critical race theory reading of the first draft. As well as helping SMP to refine its processes, this analysis suggests that minority groups such as Roma need to be able to draw upon more literary representations of Roma in order to shape their creative outputs and that the curriculum needs to focus on developing children's critical responses to the representation of minority ethnic groups in children's literature.
\end{abstract}

Tom Dobson is a founder member of Story Makers Press and a research practitioner with expertise in creative writing pedagogy.

Lisa Stephenson is the director of Story Makers Press and a research practitioner with expertise in drama pedagogy wellbeing.

Ana De Arede is the publisher of Story Makers Press and her expertise is in publishing.

Tom Dobson

t.w.dobson@leedsbeckett.ac.uk

Lisa Stephenson

1.s.stephenson@leedsbeckett.ac.uk

Ana De Arede

A.F.Sanches-De-Arede@leedsbeckett.ac.uk

1 Leeds Beckett University, Headingley Campus, Carnegie Hall, Leeds LS6 3QS, UK 
Keywords Roma $\cdot$ Children's literature $\cdot$ Primary school $\cdot$ Creative writing

\section{Introduction}

This article explores the processes involved in the co-construction and editing of the third children's book published by Story Makers Press (SMP), Chasing the Volcano, 2020. SMP is a University-based publisher of children's books, which has two key interrelated aims. Firstly, SMP publishes books which represent groups of children who are under-represented in children's literature. This is in line with research undertaken by the Centre for Literacy in Primary Education (CLPE, 2018) and Harris et al. (2019), which emphasises the under-representation of black and minority ethnic groups as well as the way in which representations of these groups are often tokenistic rather than culturally specific. What neither of the studies focuses on, however, is the depiction of Roma characters in children's literature. Whilst the 2011 census is unable to provide accurate information on the number of Roma people living in the UK due to issues with participation, Barsony and Le Bas (2016) estimate that there are about 200,000 Roma people living in the UK.

SMP's second aim is to involve under-represented groups of children in the actual co-construction of stories for publication. This is achieved through a series of drama and creative writing workshops, which empower children to make decisions about setting, character and plot. The idea is underpinned by an attempt to disrupt the typical power structures involved in children's literature whereby adult authors, editors and publishers determine and construct permissible representations of childhood. Nikolajeva (2010) refers to this as "aetonormativity"- the way that adult perceptions of normality pattern texts to influence children's behavioural and attitudinal responses.

Writing about SMP's first book, The Nightmare Catcher, Dobson et al. (2019) identify the ways in which the children's "funds of knowledge" (Moll, 1992) relating to "gaming" serve to disrupt aetonormativity. For Chasing the Volcano, the SMP team worked with a group of nine 8-11-year-old primary school children from an inner city area of social disadvantage in the north of England. The nine children were all relatively new to English and seven of the children were from Czech or Slovak Roma backgrounds. In this article we explore the ways in which these children disrupted aetonormativity, particularly in relation to establishing a genre of magical realism. We also explore tensions that arose when the children's representations of the Roma protagonist are viewed from a critical race theory perspective, which aims to challenge the perpetuation of Roma stereotypes in literature. Highlighting these tensions, we reflect upon our own processes as well as implications for curriculum knowledge and pedagogy in primary classrooms to enable children to draw more freely and more critically upon their cultural funds of knowledge in order to transform their experiences in creative ways. 


\section{Literature Review}

\section{Roma and Difficulties of Identification}

Farget (2012) identifies the Roma people as one of the largest minorities in Europe, with their origins in 9th century India and populations in several European countries since the 14th century. Farget highlights how despite the Roma people's situation varying from one country to another, the complex nature of this minority group is unified by their sufferance as they have been "particularly affected by the phenomenon of exclusion and discrimination" (2012, p. 292).

This idea of "exclusion and discrimination" can be seen in the problematic ways in which the Roma children in this project are identified. As indicated above, the research took place in an inner city school in the north of England. Of the nine children we worked with, the children's English Teacher identified seven as Roma, five from Slovakia and two from the Czech Republic. The English Teacher was also quick to point out that the children would not necessarily identify with the term Roma: "the children don't really know what Roma means-they're Gypsies". However, the English Teacher then went on to explain that not many of the children would not outwardly identify with the term "Gypsy" either, probably because they felt there was some stigma attached. In line with this, she estimated that despite the official statistics for the school's Roma children being lower, about $20 \%$ of the pupils in the school were from Roma backgrounds but that it was difficult to tell as many of the parents were reluctant to identify their children as Roma.

Given the complexity of identification of Roma and given that throughout our work with them none of the seven children explicitly referred to their ethnicity, in this paper we will refer to the children as coming from either Slovak Roma or Czech Roma backgrounds.

\section{Disrupting Aetonormativity: the "Might" in Children's Literature}

Literary criticism of children's literature often explores how the adult author exerts power over the child reader. As Hunt says, "the writers and manipulators of children's books are adults; books are the makers of meaning for their readers, and the readers are children" (1994, p. 2). Taking an extreme view of power, Knowles and Malmkjaer view children's literature as part of an ideological apparatus which is as "a particularly effective agent in promoting the acceptance by the child of customs, institutions and hierarchies" (1996, p. 44). In response to these views of power in children's literature, Beauvais (2012) adopts Nikolajeva's (2010) concept of "aetonormativity", which claims that adult perceptions of what is normal "pattern" children's literature. Beauvais (2012) highlights that there are a number of "powers" at play within the concept of aetonormativity and that these powers are not one-directional. For example, the power of "authority" is unstable as an adult author's "authority" is often transgressed by child readers who become meaning makers and, therefore, "authors" of texts. This idea is in line with reader response theory and demonstrated by Brooks and Browne (2012) who illustrate how a child's 
"homeplace" - their ethnicity, their community, their family, their peers - acts a lens through which to make meaning from a fiction text.

Explaining the etymology of the French word for power ("pouvoir"), Beauvais (2012) highlights how power is inextricable from potential and how future meanings of texts change (what she calls "might"). The idea of "might" is in line with reader response theory and Brooks and Browne's concept of "homeplace" but it is also based on the fact that unlike other theories of power in literature (e.g. feminism, postcolonialism), aetonormativity acknowledges that the child is not completely "other" to the adult as the adult was once a child too. A fiction text, therefore, always already presents the "might" for patterns of behaviour and experience not deemed normative by adults.

What the idea of "might" in children's literature does not take into account, however, is the possibility of an initial site of textual authorship which is shared by adults and children. If children's voices become part of the textuality of the text, then the child reader is ultimately less likely to be constructed by aetonormativity. Instead, there is the potential for the writers and the readers to hold more equal power relations and be as constructive in their meaning making as each other.

\section{Co-constructing Fiction with Roma Children in a Community of Writers}

Theories of power in literary criticism of children's literature view the text as discourse. This idea of the fiction text as discourse is underpinned by the work of Bakhtin, whose work spans the traditional divide between the sociolinguist and the literary critic. As a sociolinguist, Bakhtin (1981) identifies how our discourse is multiple, belonging to ourselves and to others - a structuring which he calls "heteroglossia". As a literary critic, Bakhtin (1986) illuminates how the novel is a form of heteroglossia which is dialogised by the reader through reading. What this means is that through dialogisation meanings are made in relation to the novel and that these meanings change in a never ending process which avoids heteroglossia becoming stratified is a fossilised way. Instead, discourses become "hybrid" (Bakhtin, 1986) as they enter into dialogue with each other through the reader. Literary critics analysing children's literature tend to limit the potential of the child reader to dialogise heteroglossia by seeing the child reader as manipulated by adult discourses of aetonormativity at play within the texts. If the child reader, however, was also to some extent an author of the text, then, we would argue, this would necessarily alter the patterning of heteroglossia in the fiction text and in doing so disrupt aetonormativity.

The idea of teachers writing with, for and alongside the children in their classes stems from research which shows that the teacher adopting a writer identity can help form a "community of writers" (Cremin and Myhill, 2012). In a community of writers, teachers and children share their ideas and writing processes and in doing so provide formative feedback to one another which in turn scaffolds each other's writing. This idea was harnessed by Dobson (2015) in a project which saw him co-constructing stories with primary school children as part of his PhD. In order to think about the nature of the co-authored texts which emerged, Dobson adopted Bakhtin's (1981) concept the "superaddressee" — an ideal reader who responds to a text just 
as the writer intended. Whilst reader response theory renders the actual existence of the superaddressee impossible, the idea became useful as a heuristic device to think about the extent to which the children in the writing of their stories apprehended what Dobson (2015) perceived at the time to be his superaddressee. In short, what became clear was that child writers would always to some extent replace Dobson's (2015) superaddressee with their own superaddressees, creating fictional worlds and characters that were not anticipated.

Just as Brooks and Browne (2012) use the concept "homeplace" to understand children's reading of texts, Dobson uses Moll's (1992) concept of "funds of knowledge" to understand the children's superaddressees. In relation to their creative writing, children's "funds of knowledge" encompass aspects of school and home identities and experiences, which Dobson (2015) viewed as being the raw materials which were drawn upon and transformed by the children in the act of writing. And because the children's "funds of knowledge" created superaddressees which were different to Dobson's superaddressee, Dobson saw the emerging co-constructed fictional texts as examples of "hybrid" discourses (Bakhtin 1986), where new meaning was created through the dialogisation of a heteroglossia which included children's voices and discourses. In this sense, the co-constructed texts disrupt aetonormativity by capturing how children experienced their worlds in response to how Dobson experienced his world (2015).

A key difference, however, between those texts and the text under discussion here is that Chasing the Volcano has undergone a full publishing process with the idea that it will be a marketable product. This means that whilst the initial story was coconstructed by SMP and the children, and whilst the children's responses to the first draft were part of the editing processes, there were also several other adults involved in the editing process. Adult involvement in the editing of texts written by children can serve to silence the children's voices, as illustrated by Todoroa's (2017) analysis of how a child's experiences of war became westernised for publication. Rather than elide this editing process, in the analysis of the data below, attention is paid to the dialogic relationship between the adults and the children in the writing and editing processes. In particular a tension is articulated between the children's construction of the Roma protagonist in the story and the way this was read by an Adult Reader (AR) from a Roma background who was employed by SMP to undertake a sensitivity reading.

\section{Roma in Children's Literature: Polarised Representation and Counter-Stories}

This relationship between the children's construction of the Roma protagonist and AR's response is explored in the Findings section below and in many ways AR's reading is consistent with the ways in which literary critics have discussed the representation of Roma in children's literature over the last 30 years. Hancock (1987, p. 47), for example, undertakes an analysis of the Gypsy in children's literature, identifying that the Gypsy character tends to serve one of three functions: "liar and thief... witch or caster of spells... romantic figure". Toninato (2014, p. 150), identifying how nomadism is at once romanticised and at the same time held to be 
the epitome of "lawlessness and social deviance", seeks to explain this tendency to place Roma characters in a "polarised system of representation" as "typical of the dominant portrayal of minority groups". Focussing on the child-snatching myth in Victorian children's literature, Matthews (2010, p. 155) identifies how the "othering" of the Gypsy as evil acts as a kind of "reassurance" to readers where "racial categorisation remains unproblematic".

What is missing from children's literature are culturally-sensitive portrayals of Roma characters. Dean-Ruzicka (2014), for example, finds this to be the case in young adult holocaust fiction, where two out of the three books analysed reveal Roma-Siniti characters' culture is explored in a superficial way. One way of escaping this polarised system of representation is identified by Toninato (2018), who analyses autobiographical writings where Roma people themselves have written about nomadism. Toninato (2018, p. 153) identifies how nomadism "is frequently portrayed as an allegedly carefree existence [but] is in fact a reality dominated by violence and oppression". Similarly, but within the sphere of education, D'Arcy (2017) collects "counter-stories" from Roma families and juxtaposes these counter-stories with myths about Roma mobility and educational aspirations. Operating within a critical race theory framework, D'Arcy (2017) gives voice to the voiceless and actively challenges dominant cultural discourses. In relation to this project, we were interested in exploring how Roma children would depict Roma characters in their story and the extent to which their depiction could be considered a counter-story.

\section{Research Questions}

In line with the theoretical framework outlined above, four key research questions emerged throughout the course of this project:

1) From a cultural perspective, what kinds of characters would populate the children's fictional worlds and to what extent would they disrupt aetonormativity?

2) What funds of knowledge would the children draw upon in populating the fictional worlds and who would be their superaddressees?

3) How should SMP frame the workshop sessions to facilitate the representation of Roma characters?

4) What is the dialogue between the children's depiction of Roma characters and AR's response?

\section{Methodology}

\section{Ethics}

Having received institutional ethical clearance for the project, the headteacher gave their informed consent and the children were recruited in two phases: firstly, the English Teacher approached children who were new to English and predominantly from Roma backgrounds to volunteer to take part in the project; secondly, those 
children who agreed to take part in the project were informed about the nature of the project and its dissemination by the SMP team at the beginning of each workshop and verbal assent for participation was sought in a way that was ongoing.

We also agreed with the headteacher and the children that, as the book was coauthored by the children, the author would be listed as The Story Makers Collective and inside the book the school would be listed as part of that Collective. In doing so, we ensured that we adhered to the ethical guidelines of the British Education Research Association by protecting confidentiality through anonymising all of the children when writing about their contributions. We also gained informed consent by the adults involved in this project.

\section{Context}

For Chasing the Volcano, two academic practitioners in Higher Education and the SMP Publisher undertook drama and creative writing workshops with nine new to English, mixed gender, 8-11-year-old children. The workshops took place in an inner city primary school, located in an area of lower socio-economic status in the north of England where approximately $20 \%$ of the children are from either a Czech or Slovak Roma background. Of the nine children with whom we worked, five were from a Slovak Roma background and two were from Czech Roma background. The English Teacher was also keen to invite two other children to be part of the group, refugees recently arrived from Syria and Iran respectively. Given the focus of this paper and the research questions outlined above, here we focus mainly on the participation and contributions of the Roma children in the group. Having said this, given the fluid nature of the workshops themselves and the processes of co-construction, we also analyse data relating to the contributions of the children from Syria and Iran.

\section{The Workshops}

As outlined in Table 1, we ran a total of six 2-hour drama and creative writing workshops with the children over a two-month period. The workshops were informed by our own practitioner research (Dobson and Stephenson, 2017; Dobson et al., 2019), where we utilise process drama to give children an embodied experience which they transform into writing and drawing. Process drama is a "weakly framed" (Bernstein, 1990), child-centred pedagogy which uses drama conventions to facilitate children actively co-constructing meaning as they fluidly move between the roles of authors, actors, directors and audience (Edmiston, 2014). Working within the fiction, the children were given writing journals and we encouraged them to use these to write and draw from the perspective of the characters they were portraying. As Crumpler (2005) illustrates, writing in the fiction rather than outside the fiction adds a dramatic quality to children's writing as the immediate translation of experience into writing and illustrations means that what is captured are "dramatic textual events". Because the children in this group were new to English, they often chose drawing rather than writing as a way of capturing and conveying their ideas. At times, the 


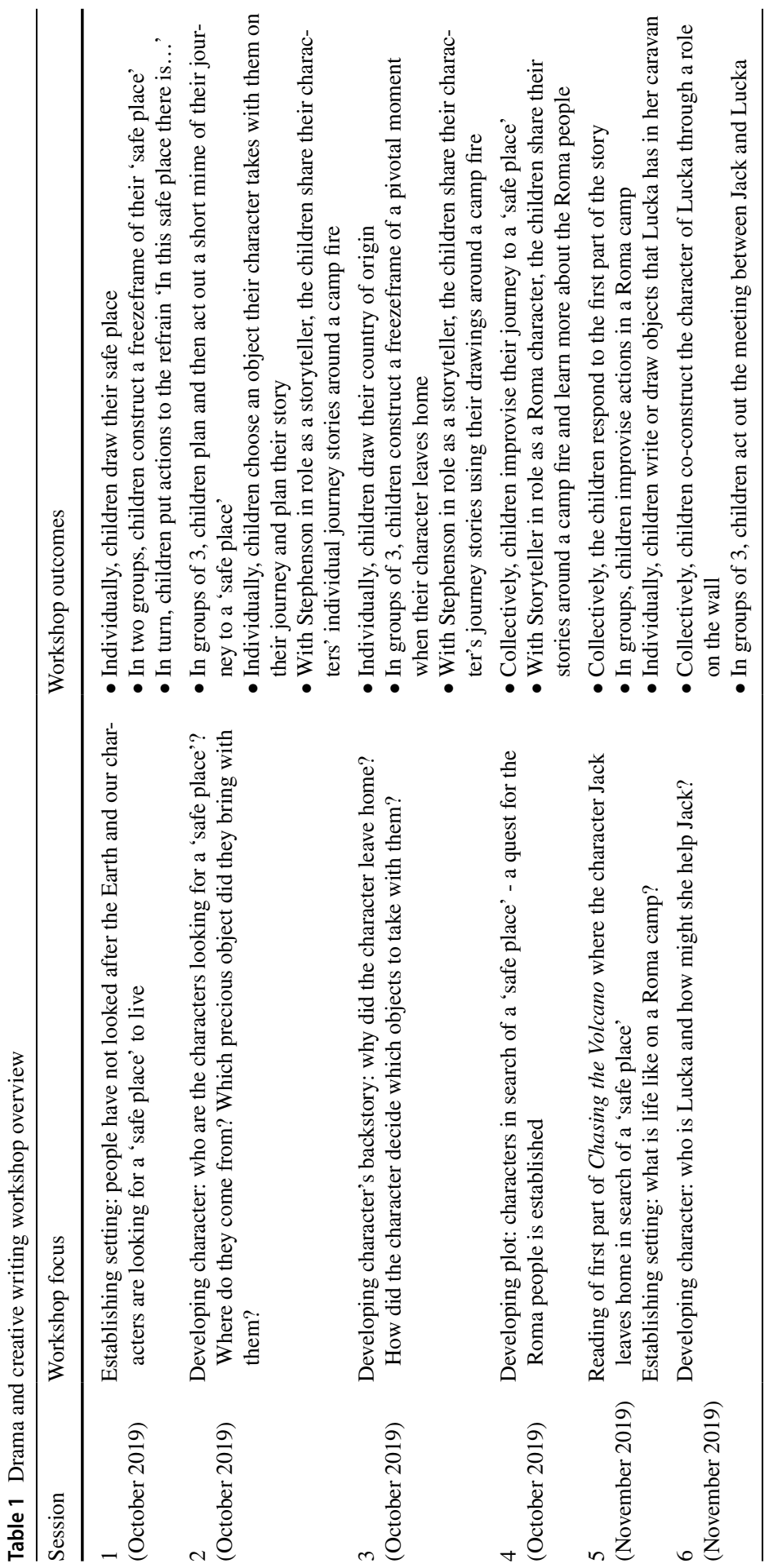


children's work was individual, but on the whole they worked in small groups to share and develop their ideas about setting, character and plot.

Prior to the first session, we spoke with the children's English Teacher and a Storyteller, who worked closely with the school and was from a Roma background. The English Teacher explained that most of the work she undertook with the children was "grammar" based and this meant that the children did not have much prior experience of drama or creative writing. For this reason and because the workshops were on the whole once a week, the activities we undertook with the children often involved repetition. The Storyteller helped us to establish a frame for our workshops. He was keen to include the idea of the nomad and to develop the children's historical understanding of the Roma people and their Indian heritage. He talked about how the Roma people "travelled", were "close to nature" and could make things from "wood and metal". Taking some of these ideas on board, we wanted to place the story in a modern setting, which would engage the children, but where nomadism could be more prevalent. For this reason and because it is a pressing global concern, we decided to frame our story within a global climate change catastrophe where "people had not looked after the Earth and were now looking for a safe place to live." We felt this setting would provide scope for the children to discover the skills and knowledge of the older Roma generations as emphasised by the Storyteller. As we explore below, this decision to frame the story as story of nomadism in a context of climate change may have contributed to some of the tensions evident between the children's construction of the Roma protagonist and AR's reading of this.

\section{Data Generation and Co-constructing Chasing the Volcano}

The workshops were led by Stephenson who positioned the children as active participants who had agency in co-constructing their emerging narrative for the book. Here, data were generated through the use of writing journals where the children used writing and illustrations to capture their ideas as they worked in the fiction through process drama. The ways in which the children participated in process drama activities were captured through video recording the sessions. Following each workshop, SMP team members met to review the video footage of the session alongside the children's writing journals. During these meetings, decisions were made about the characters, the setting and plot, which incorporated the children's ideas and which helped to plan the subsequent workshop activity. Our thoughts and decisions were captured in individual research journals. In these journals we also reflected on our positionality within the project-as none of us are from Roma backgrounds, we were aware of difficulties in facilitating the children in the representation of culturally sensitive Roma characters.

Our positionality meant that semi structured interviews undertaken with the children's English Teacher and the Storyteller at the start of the project were particularly useful. The interviews helped us to understand the context of the school, how the children worked together and the kind of themes we could explore within the book.

The text for Chasing the Volcano was written throughout the workshops by Dobson, drawing upon the children's emerging ideas and language choices. Following 
workshop 4, Dobson completed the first half of the story and read this to the children for feedback in workshop 5. The first draft of the text was then completed by Dobson following workshop 6 and was shared with the children in a separate session to gain feedback.

As part of the editing process and to mitigate against SMP's non-Roma positionality as outlined above, SMP's publisher solicited feedback on the first draft from an Adult Reader (AR) from a Roma background through a collective who undertake sensitivity readings on draft manuscripts. AR's feedback on draft 1 of Chasing the Volcano, as well as subsequent changes undertaken by Dobson in the writing draft 2, are included as data for this article.

\section{Data Analysis}

Following each session, we discussed our research journal entries in order to develop the story we were writing, plan subsequent workshops and explore and refine our research questions. This meant our methodology was via 'practitioner enquiry,' we sought to reflect upon how successful the workshops had been in encouraging and harnessing the ideas of the children in the group. In doing so, we also began to analyse the data, synthesising our reflections with theory (Cochran-Smith and Lytle 1993), in particular with notions of aetonormativity, hybridity and representation of Roma, as well as what this meant in terms of the emerging narrative. These early analyses became the main content of our research journals.

Once the project was completed, we undertook a further thematic analysis of all the data: our journal reflections; drawings and writing produced by the children in the workshops; video recordings of the sessions; transcripts interviews with the English Teacher and Storyteller; written feedback on draft 1 of the story from AR; and differences between draft 1 and draft 2 of the story. Our thematic analysis was in part deductive as we used our theoretical frame to think about the funds of knowledge the children transformed in order to address their superaddressees and the extent to which this disrupted aetonormativity. At the same time, our thematic analysis was also inductive as our research questions evolved throughout our practitioner enquiry and as we remained open to the specific ways in which the Roma children's funds of knowledge were enacted and how this might specifically relate to their lived experiences. Accordingly, three themes emerged, which are discussed below: the children's superaddressees and a protagonist called "Jack"; the Harry Potter effect and magic realism; removing the magic and the traditional in the depiction of Roma characters.

\section{Findings and Discussion}

\section{The Children's Superaddressees and a Protagonist Called "Jack"}

Throughout the first four workshops, the children developed their own protagonists who were looking for a 'safe place' as a result of a climate change catastrophe. 
These protagonists were all unstable, with their names, their countries of origin and destination as well as their backstories fluctuating from week to week. As reflected in our research journals, the reasons for this instability were three-fold: firstly, it was due to the fact that at times the children developed their protagonists individually and at other times in groups; secondly, it was due to the different ways in which the SMP team framed the development of the protagonists during different workshop sessions; and thirdly, it was because the children's protagonists evolved over time as the children explored their characters further.

After the first session, the SMP team observed that the children had tended to either "Westernise the setting of their story" or choose a setting which was "wellknown globally". Accordingly, one group of children had set their story in New York; the other next to the River Nile. The SMP team were keen to avoid co-constructing a story with the children which did not include Roma characters and as a result they planned to reframe the setting of the children's emerging stories in workshop 2. To do this they referred back to their interview with the Storyteller and introduced a stimulus which would provide slightly stronger "framing" (Bernstein, 1990) for the activity — a bag of objects, some of which pertained to traditional Roma culture, including: a photograph of a caravan; a small figure of a metal angel; a peg doll; a Russian doll; a precious stone bracelet; a wooden whistle carved into the shape of an owl; a shiny gold object with an inscription in a foreign language; a box containing three small and smooth volcanic stones; and a checked scarf. In workshop 2, each child was invited to choose an object and develop their protagonist's backstory, telling the story of their journey around a camp fire and explaining to the others why they had brought their object with them. Interestingly, in telling their individual stories, all but one of the children drew upon their home cultural identities, employing their own countries of origin as the home countries for their protagonists.

If the objects had been successful in encouraging the children to draw upon funds of knowledge from their cultural heritage to develop their protagonists, this shift in the children's imaginative thinking did not permeate into the following session. By the end of workshop four, seven out of nine of the children from Roma and non-Roma backgrounds had decided upon names for their protagonists which were Western and which reflected their own genders (one child from a Roma background did not explicitly name her character; another child chose a traditional Roma name, Lucka). The male names chosen by the male Roma children were Jack, Danny and Tom; the female names chosen by the female Roma children were Kristina and Lily. Accordingly, the Westernisation of the children's protagonists was reflected in the countries the characters were fleeing in search of a safe place. Again, the countries became unstable as the workshops progressed but their Western protagonists were from places like America, London, Australia and France, as well as globally wellknown locations in line with the theme of climate change, including Antarctica, Mount Everest and a non-specific volcano.

What became apparent was that as a community of writers engaged in process drama, the children were often reluctant to co-construct a story for a superaddressee who would be interested in reading about the journey of a Roma protagonist. In this sense, the protagonists the children constructed could be seen as disrupting the 
SMP team's aetonormativity for the book they were looking to write and publish. What the stronger "framing" (Bernstein, 1990) of workshop 2 demonstrates is that the funds of knowledge relating to personal cultural experiences to write about a Roma protagonist were certainly available to the children. However, when the sessions were more weakly framed, the children tended to forget these funds of knowledge, confound our adult normality with which we were patterning the book, and construct stories for a Western superaddressee.

At the start of the project the English Teacher identified how Roma children write for a Western audience, giving their characters white Western names. According to the English Teacher, this was because "all the books in the school never represent Roma children", indicating that the Roma children did not have literary funds of knowledge where Roma characters are depicted to draw upon and transform. This might in part explain what was happening in the decisions the Roma children were making when constructing their protagonists. The other aspect may be to do with a wider issue of the children not wanting to identify as Roma due to the ongoing historical phenomenon of "exclusion and discrimination" (Farget, 2012).

\section{The Harry Potter Effect and Magic Realism}

As a result of the children choosing to tell the story of a Western protagonist, when writing the story we chose "Jack" as the protagonist - a boy forced to leave a flooded England and look for a safe place on what is left of mainland Europe. Whilst Jack's story could incorporate many of the ideas of the children, we also wanted to include a story from a Roma character's point of view. In our meeting after workshop three, therefore, we decided to use stronger framing and decided that Jack would meet a Roma girl called Lucka (the one non-Western name attributed to a protagonist by a girl from a Czech Roma background) in Eastern Europe and that she would save Jack and tell him her story. Accordingly, the last two sessions focussed on developing the character of Lucka and the setting of the camp where she and her family were living.

In constructing both of the protagonists, we reflected upon how the children situated the story within "the genre of magic realism". The sense of realism was a response, we felt, to our superaddressee, who would want the story to explore the serious issue of climate change and what the repercussions of this might be for characters. Apprehending our superaddressee, in the earlier workshop sessions, which largely formed Jack's story, the children drew, wrote and acted out scenes where "plastic bottles" were "poisoning oceans", where the "river Nile" was "full of plastic", where society had broken down and buildings were "crumbling" and where "mean people" and "angry people" were "fighting" and "smoking", one even trying to "kidnap" children. There was also a keen sense that the basic necessities were of importance to the protagonists, with "clothes", "food" and "water" frequently mentioned, as well as more luxury items like a "PlayStation". Similarly, in the later sessions where the children explored Lucka's story, there was a focus on sustainability in relation to "fixing things", "looking after horses" and "growing own plants to 
eat". The characters in the camp also made objects like "dolls" to sell on "stalls", where they would sometimes sell their produce and their "medicines" too.

Whilst the framing of the story by the SMP team required the children to meet the needs of our jointly apprehended superaddressee, who was interested in a realistic exploration of climate change, the way the children consistently interwove the real with the magical in both Jack and Lucka's story illustrates how the children took control of the genre of the story and in doing so disrupted aetonormativity, coming up with ideas we would never have imagined for a superaddressee of their own construction. In the earlier sessions, which formed Jack's story, the children depicted their protagonists as travelling with a range of magical objects. There was a "magical book" which contained a map of the safe place; there was a "magic hat" which the children said was "like the one in Harry Potter" and which would tell the protagonist where to go; and there were volcanic stones, one of which acted as a "compass", while another, when pressed to a throat, disguised the voice of the speaker. In the later sessions which formed aspects of Lucka's story, Lucka was said to own a "book of Harry Potter". The children agreed that she "knows about magic", had a "magical chair with invisible legs", and could make a range of potions for "danger, disguising, growing hair and if you are polly" (poorly).

As illustrated, the children were aware of the extent to which they drew on their funds of knowledge relating to the Harry Potter books to develop the magical capabilities of their protagonists and meet the needs of a superaddressee who liked reading fantastical adventure stories. However, some of the children's ideas relating to magic were less derivative, notably the volcanic stones and the potions. When set against their realistic portrayal of climate change, these ideas produced an original effect in line with the genre of magical realism, which would be more appealing to a child superaddressee than a story which was wholly grounded in realism. It was this aspect, the crossing genres between the realistic and the magical, as well as the children's initial reluctance to write a Roma protagonist, which meant that the children's contributions to Chasing the Volcano disrupted the SMP team's sense of aetonormativity.

\section{Removing the Magic and the Traditional in the Depiction of Roma Characters}

Whilst the children were enthusiastic in their response to the first draft of Chasing the Volcano, AR highlighted some problems with the magical portrayal of Lucka, which were addressed in the second draft. This is in line with literary criticism of Roma representation in children's literature which views Roma characters placed in a "polarised system of representation" Toninato (2014). Rather than being a "counter-story" (D’Arcy, 2017), which offers a culturally sensitive depiction of what life is really like for Roma people and in doing so disrupts culturally held myths, for AR we had lapsed into a mythical representation, both in our evocation of the magical and in the way in which we had portrayed the Roma community as nomadic.

Specifically, AR felt that by depicting Lucka as having magical powers and being able to making "potions" to heal people, the story was re-enforcing "stereotypes about Roma as a fairy tale creature of fiction as opposed to a real community with 
people no different than those of general society." For AR this "fairy tale" depiction of Lucka was in line with "false narratives used against Roma, especially by religious institutions to justify racial oppression.” Linked to Lucka's potion making, AR also questioned the way in which we had portrayed the wider Roma community and their "manual labour skills, cooking, working the earth, and speaking around the fire". For AR this "traditional" portrayal was often "used by wider society to romanticise the past of Roma people and invalidate the modern and current issues" they face.

The SMP team reflected upon AR's feedback and discussed possible changes to Lucka's story. We were mindful that Lucka making magical potions had been an idea which came from the children, in line with their overall casting of the story within the magical realism genre. We discussed how the Western character of Jack had his magical powers too, most notably in his use of the volcanic stones to find his way to the volcano and disguise his voice to protect his identity. We were also mindful that our depiction of the Roma community as nomadic was in part due to the ways in the SMP team and the Storyteller had framed the sessions. From the beginning, the decision to set the story in a post climate change world necessitated a story where all of the characters became nomadic. Added to this, the Storyteller's input before the project started and with the children in workshop 4, developed the community of writers' understanding of the traditional skills and knowledge of the Roma people as nomads. Together, this provided a framing whereby the children's depiction of the Roma community was one of being able to cope with the climate change situation and help Jack.

Taking this into consideration, we also felt it was important that through the depiction of Lucka as a fairy tale character and the Roma community as traditional nomads, Chasing the Volcano did not perpetuate stereotypes of Roma people which served to "invalidate the modern and current" issues which they faced. As a result of this, we made a number of changes to the first draft, including replacing Lucka's making of "potions" with her learning of how to make "herbal remedies" from her aunty Daiena. With this, we were keen to ensure that Daiena was not depicted as a traditional herbalist, but rather as someone who had learnt these skills online as a result of the climate change and the enforced nomadism that had ensued. Daiena was then passing these skills onto Lucka, who in telling her story of her own schooling has clear aspirations to become a doctor in the modern world:

"I learnt how to make medicines from herbs! My aunty Daiena said that without factories to make medicines, doctors like me would have to use herbs and she taught me what the different leaves could do for the human body and how to harness the power in the leaves to make medicines that would cure every illness on this planet. A green one for strength. An orange one for fever. A red one for bald men!"

The idea of depicting the Roma characters as "modern" was something that was already part of the first draft of Lucka's story, which starts by her telling Jack about how her family moved to England due to economic hardship, how she loved school and wanted to be a doctor, how they experienced discrimination and how they re-joined their family as a result of climate change. Based on AR's feedback, 
we acknowledged there were moments, like Daiena's seemingly innate ability to be a herbalist, which placed the Roma community in a mythical place and time. An example of this relates to the position of mobile phones in the narrative. Throughout Jack's journey, he clings onto his mobile phone as a source of comfort and potential connection with his lost family. In the first draft of the story, when Lucka finds him and takes him to her camp, Jack realises the futility of the mobile phone and when he discards it, "some of the people around the fire clap, one even lets out a cheer." We reflected upon how the reaction of the Roma community depicted them as not inhabiting the modern world and in the second draft we deleted this line and had Lucka's dad talking about discarding his mobile phone: "I gave up mine soon after we joined the caravan."

AR's feedback and changes to the first draft of Lucka's story illustrated two key points. Firstly, in removing the magical from the children's chosen genre of magical realism we are aware of how the children's disruption of aetonormativity in defining the genre for their story was in conflict with an adult critical race theory reading of the text. Secondly, in setting the story post climate change and framing the Roma community as having the skills and knowledge able to cope with the ensuing nomadism, we acknowledged that our activities with the children led at times to a romantic depiction of Roma which was also in tension with critical race theory.

\section{Conclusion}

There is a range of key implications relating to the findings above, for SMP, for publishers of children's fiction and for educators working with Roma children. Firstly, with regards to SMP, we recognise the difficulties of working with underrepresented groups of children to represent those groups in publishable stories. This seemed particularly difficult when working with Roma children, who were often reluctant to draw upon their cultural funds of knowledge to co-construct the setting, characters and plot for our story. Our subsequent stronger "framing" (Bernstein, 1990) of sessions to ensure the depiction of Roma characters in the book caused us to co-construct romantic Roma characters which perpetuated a "polarised system of representation" (Toninato, 2014). Taking this into account, in future projects we would continue to anticipate carefully the narrative implications of our framing of the story and the sessions. AR's role as a sensitivity reader certainly helped us but the fact that AR was our one adult member from a Roma background also potentially essentialised issues of ethnicity. A solution would be to incorporate feedback from a number of ARs from the target ethnic group, although this could, in turn, be difficult to manage. Perhaps more importantly, we would aim to include the children in ongoing discussions about representation too.

Secondly, the fact that Roma children created Roma characters which an adult Roma reader criticised for being "stereotypes" indicates that these children, and by inference other children, are not exposed to authentic representations of diverse cultural groups in literature. As a result of this, the Roma children were unable to draw upon literary funds of knowledge relating to Roma to shape their creative output. Here it is clear that despite some improvements in diversity of representation in 
children's literature (CLPE, 2018) more still needs to be done within publishing to represent ethnic minority groups such as Roma.

Furthermore, it could be extrapolated that where stereotypical depictions of characters are encountered in a primary classroom, they are not always questioned or critiqued. This lack of critical literacy could be seen as symptomatic of wider neoliberal forces and a National Curriculum in England which focuses on technical skills that can be measured and tested in the form of statutory exams. A shift in curriculum policy towards critical literacy allied with teacher professional development to use theories like critical race theory to analyse texts would help.

Finally, more research needs to be undertaken to see how real children respond to texts such as Chasing the Volcano. Brooks and Browne's (2012) culturally sensitive analysis of how children's meaning making when reading is mediated by their "homeplace" is an excellent illustration of how nuanced the act of reading actually is. The SMP team will, therefore, investigate the responses of children to this book and others which have been co-constructed with children. With this in mind, it will interesting to explore how children's disruption of aetonormativity in the co-construction of texts is responded to by child readers in specific cultural contexts.

Open Access This article is licensed under a Creative Commons Attribution 4.0 International License, which permits use, sharing, adaptation, distribution and reproduction in any medium or format, as long as you give appropriate credit to the original author(s) and the source, provide a link to the Creative Commons licence, and indicate if changes were made. The images or other third party material in this article are included in the article's Creative Commons licence, unless indicated otherwise in a credit line to the material. If material is not included in the article's Creative Commons licence and your intended use is not permitted by statutory regulation or exceeds the permitted use, you will need to obtain permission directly from the copyright holder. To view a copy of this licence, visit http://creativecommons.org/licen ses/by/4.0/.

\section{References}

Bakhtin, M.M. (1986). Speech Genres and Other Late Essays. Austin, TX: University of Texas Press. Bakhtin, M.M. (1981). The Dialogic Imagination: Four Essays. Austin, TX: University of Texas Press. Barsony, K. and Le Bas, D. (2016). Before You Make Another Offhand Remark About Roma and Travellers in the UK, We'd Like to Tell You This. Independent. https://www.independent.co.uk/voice s/before-you-make-another-offhand-remark-about-roma-and-travellers-in-the-uk-wed-like-you-toconsider-a7168506.html.

Beauvais, C. (2012). The Problem of 'Power': Metacritical Implications of Aetonormativity for Children's Literature Research. Children's Literature in Education, 44, 74-86. https://doi.org/10.1007/ s10583-012-9182-3.

Bernstein, B. (1990). The Structuring of Pedagogic Discourse. London: Routledge.

Brooks, W., and Browne, S. (2012). Towards a Culturally Situated Reader Response Theory. Children's Literature in Education, 43, 74-85. https://doi.org/10.1007/s10583-011-9154-z.

CLPE (2018). Reflecting Realities - Survey of Representation within UK's Children's Literature 2018. https://clpe.org.uk/RR.

Cochran-Smith, M., and Lytle, S. (1993). Inside/Outside: Teacher Research and Knowledge. New York: Teachers College Press.

Cremin, T., and Myhill, D. (2012). Writing Voices: Creating Communities of Writers. London: Routledge. Crumpler, T. (2005). The Role of Educational Drama in the Composing Processes of Young Writers. Research in Drama Education, 10(3), 357-363. 
D’Arcy, K. (2017). Using Counter-Stories to Challenge Stock Stories About Traveller Families. Race Ethnicity and Education, 20(5), 636-649. https://doi.org/10.1080/13613324.2016.1191701.

Dean-Ruzicka, R. (2014). Representing “'The Great Devouring:" Romani Characters in Young Adult Holocaust Literature. Children's Literature in Education, 45, 211-224. https://doi.org/10.1007/ s10583-014-9217-z.

Dobson, T. (2015). The Mad Genie in the Attic. Gender and Education, 27(1), 37-52. https://doi. org/10.1111/eie.12075.

Dobson, T., and Stephenson, L. (2017). Primary Pupils' Creative Writing: Enacting Identities in a Community of Writers. Literacy, 51(3), 162-168. https://doi.org/10.1111/lit.12118.

Dobson, T., Stephenson, L., and De Arede, A. (2019). Disrupting Aetonormativity: Involving Children in the Writing of Literature for Publication. English in Education. https://doi.org/10.1080/04250 494.2019.1679622.

Edmiston, B. (2014). Dialogue and Social Positioning in Dramatic Inquiry: Creating with Prospero. In S. Davis (Ed.), Dramatic Interactions in Education - Vygotskian and Sociocultural Approaches to Drama Education and Research (pp. 66-79). London: Bloomsbury.

Farget, D. (2012). Defining Roma Identity in the European Court of Human Rights. International Journal on Minority and Group Rights, 19, 291-316.

Hancock, I. (1987). The Origin and the Function of the Gypsy Image in Children's Literature. The Lion and the Unicorn, 11(1), 47-59. https://doi.org/10.1353/uni.0.0227.

Harris, C., Stiell, B., and Leather, D. (2019). Time for Change: Black and Minority Ethnic Representation in the Children's Literature Sector. Sheffield: Sheffield Hallam University.

Hunt, P. (1994). An Introduction to Children's Literature. Oxford: OUP.

Knowles, M., and Malmkjaer, K. (1996). Language and Control in Children's Literature. London: Routledge.

Matthews, J. (2010). Back Where They Belong: Gypsies, Kidnapping and Assimilation in Victorian Children's Literature. Romani Studies, 20(2), 137-150.

Moll, L.C. (1992). Literacy Research in Community and Classrooms: A Sociocultural Approach. In R. Beach, J.L. Green, M.L. Kamil and T. Shanahan (Eds.), Multidisciplinary Perspectives in Literacy Research (pp. 211-244). Urbana: National Conference on Research in English \& National Council of Teachers of English.

Nikolajeva, M. (2010). Power, Voice and Subjectivity in Literature for Young Readers. London: Routledge.

Todoroa, M. (2017). Children's Voices from War Zones: Muted by Adult Mediation. Bookbird., 55(2), $20-27$.

Toninato, P. (2018). Romani Nomadism: from Hetero-Images to Self-representations. Nomadic Peoples, https://doi.org/10.3197/np.2018.220109.

Toninato, P. (2014). Romani Writing: Literacy, Literature and Identity Politics. London: Routledge.

Publisher's Note Springer Nature remains neutral with regard to jurisdictional claims in published maps and institutional affiliations. 